\title{
DETERMINAN FRAUD PADA PENGGUNAAN DANA DESA STUDI KASUS GAMPONG/DESA DI KOTA LANGSA
}

\author{
Early Ridho Kismawadi ${ }^{1}$
}

\begin{abstract}
Abstrak
Penelitian ini bertujuan membahas tindakan kecenderungan pada penggunaan dana desa. Pada dasarnya pemerintah desa berkewajiban mensejahterakan masyarakat desanya dengan anggaran dana desa yang telah disalurkan langsung oleh pemerintah pusat karena pemerintah desa yang langsung bersentuhan dengan masyarakat pedesaan. Akan tetapi, sejalan dengan diberikannya anggaran dana desa itu kepada pemerintah desa semakin banyak pula kecurangan yang terjadi.Pada penelitian, mengukur tingkat kecurangan pada penggunaan dana desa, pada penelitian ini menggunakan dua variabel yaitu variabel terikat (kecenderungan kecurangan pada penggunaan dana desa) dan variabel bebas (sifat love of money dan kecerdasan spritual). Hasil perhitungan regresi menunjukkan Love Of Money (XI) berpengaruh secara parsial terhadap Kecenderungan Fraud pada penggunaan dana desa. Sedangkan Kecerdasan Spiritual (X2) tidak berpengaruh secara parsial terhadap Kecenderungan Fraud pada penggunaan dana desa.
\end{abstract}

Kata Kunci: Dana Desa, Fraud, Kecurangan

\begin{abstract}
Abstrak
This study aims to discuss trends in the use of village funds. Basically, the village government is obliged to prosper the village community with a village fund budget that has been channeled directly by the central government because the village government is directly in contact with rural communities. However, in line with the village budget allocation to the village government more and more fraud has occurred. In the study, measuring the level of fraud on the use of village funds, in this study used two variables, the dependent variable (the tendency of fraud on the use of village funds) and the variable free (the nature of love of money and spiritual intelligence). The results of the regression calculations show that Love of Money (XI) has a partial effect on the Fraud Tendency on the use of village funds. Whereas Spiritual Intelligence (X2) has no partial effect on the Fraud Tendency on the use of village funds.
\end{abstract}

Keywords: Village Funds, Fraud, Fraud

1 Dosen IAIN Langsa, Email: Kismawadi@iainlangsa.ac.id 


\section{PENDAHULUAN}

Desa sebagai pemerintahan yang langsung bersentuhan dengan masyarakat menjadi fokus utama dalam pembangunan pemerintahan era Joko Widodo dan Jusuf Kalla, hal ini sesuai dengan nawacita Presiden yakni membangun indonesia dari pinggiran dengan memperkuat daerah-daerah dan desa-desa dalam rangka kesatuan. Dengan tujuan hal ini mencegah terjadinya urbanisasi dengan melakukan pembangunan yang merata diseluruh desa yang ada di indonesia. Sehingga,tidak ada lagi peralihan masyarakat dari desa ke kota untuk mencari pekerjaan. Namun, cukup tinggal di desa dengan memanfaatkan sumber daya yang ada seperti melanjutkan pertanian, perindustrian, dan lain sebagainya.

Undang-undang NO. 6 Tahun 2014 merupakan salah satu bentuk perwujudan komitmen pemerintah untuk pembangunan desa. Upaya pembangunan desa tersebut dilakukan dengan skema penataan desa. Dimana dengan penataan desa ini nantinya akan ditujukan untuk mempercepat peningkatkan kesejahteraan masyarakat, kualitas pelayan publik serta meningkatkan daya saing desa.

Tidak bisa kita pungkiri jika banyak terjadi kecurangan tidak terlepas dari adanya keinginan untuk mengambil hak orang lain dan mementingkan kepentingan pribadi atau kelompok. Padahal, di dalam al-qur'an telah jelas bahwasanya tidak dibenarkan mengambil hak orang lain, seperti firman Allah SWT. pada surah al-baqarah, 188:

Artinya: "janganlah kamu makan harta sesama kamu dengan jalan yang bathil, dan janganlah kamu membawa (urusan) harta itu kepada hakim, dengan maksud agar kamu dapat memakan sebagian harta orang lain itu dengan jalan yang berdosa, padahal kamu mengetahui". (Q.S.Al-Baqarah:188)

Tindakan kecurangan yang dilakukan seseorang juga bisa disebabkan adanya dorongan untuk mendapatkan sesuatu yang diinginkan. Salah satunya adalah kecintaan terhadap uang ( love money). Seseorang yang mempunyai kecintaan terhadap uang biasanya leih termotivasi untuk melakukan hal apapun demi memdapatkan uang yang lebih besar. Jika kita mengacu pada al-qur'an, maka kita mengetahui jika lebih mengejar urusan dunia daripada urusan akhirat tanpa mempertimbangnkan halal haramnya, adalah tidak benar. Hal ini sesuai dengan surah al-imran ayat 14:

Artniya: "Dijadikan terasa indah dunia ini dalam pandangan manusia daripada cinta terhadap syahwat (keinginan), berupa perempuan-perempuan, anak-anak, harta benda yang bertumpuk dalam bentuk emas dan perak, kuda pilihan, hewan ternak, dan sawah ladang. Itulah kesenangan hidup didunia, dan disisi Allah-lah tempat kembali yang baik”.

Ayat ini menjelaskan jika kecintaan manusia terhadap hal dunia yang dikelompokkan kedalam lima kelompok. Bahwasanya secara fitrah manusia kecintaan terhadap dunia ini sejatinya tidak tercela. Cinta dunia (hubbud dunia) akan tercela ketika seseorang men- 
gambil sesuatu yang allah benci sehingga cinta dunia (hubbud dunia) itu membentengi seseorang dari sesuatu yang allah cintai.

Selain itu, perilaku dari individu yang dipengaruhi oleh berbagai faktor salah satunya ialah spritualitas dan keimanan. Nilai-nilai spritualitas dan keimanan dari suatu kepercayaan tentu akan mempengaruhi cara individu berfikir dan berprilaku termasuk sikap dan huungan dengan orang lain. Seseorang yang memiliki kecerdasan spritual dan keimanan akan menampilkan perilaku yang sesuai dengan keyakinannya dan direfeleksikan didalam masyarakat. Hal ini telah terbukti bahwa pengaruh dari spritualitas dan keimanan yang memadai akan berdampak positif. Perilaku positif berarti individu menjadi akan lebih baik dan menampilkan perilaku yang mempertahankan etika pada menampilkan perilaku yang merusak etika seperti melakukan kecurangan.

\section{KAJIAN TEORITIS}

\subsection{Fraud Triangle Theory}

Teori yang mendasari penelitian ini ialah fraud triangle theory atau yang disebut segitiga kecurangan. Fraud triangle theory ini pertama kali dikemukakan oleh Cressey pada tahun 1953. Dalam fraud triangle theory yang dijelaskan oleh Cressey tersebut terdapat tiga faktor yang umumnya timbul pada saat terjadinya kecurangan (fraud), yaitu: tekanan (pressure), kesempatan (opportunity), dan pembenaran (rationalization).

\subsection{Penipuan Dini}

Kejahatan keuangan dan penipuan mungkin telah ada sejak awal perdagangan. Woodward et al. (2003) mencatat penggunaan biometrik yang belum sempurna ribuan tahun yang lalu sebagai cara mengidentifikasi pedagang tepercaya - kesimpulannya adalah bahwa pelaku pasar yang tidak dapat dipercaya telah ada sejak manusia mulai berdagang. Keay (1992), Robins (2007), dan yang lainnya melaporkan tentang apa yang mungkin merupakan penipuan laporan keuangan perusahaan publik pertama di British East India Company pada akhir 1600-an.

Adam Smith (1776) mengakui kekurangan korporasi modern termasuk erosi nilai pemegang saham karena pemborosan dari penipuan dan penyalahgunaan.Dengan mengingat hal ini, kami menempatkan model penipuan dasar pada Gambar 1. Model ini menyoroti pemisahan individu yang melakukan kejahatan dari tindak pidana. Selama 60 tahun terakhir, teori-teori yang lebih canggih telah dikembangkan yang membedakan penipuan dan motivasinya dari bentuk kejahatan bermotivasi finansial lain, seperti pencurian dan pencurian. Masing-masing teori penipuan memberikan perspektif penipuan yang unik serta wawasan ke dalam pikiran si penipu. Dari model konseptual dasar inilah kita mulai membangun pemahaman kita tentang penipuan dan kejahatan kerah putih. 


\section{FGURE 1}
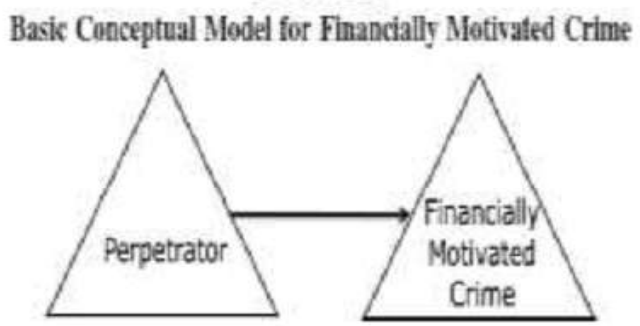

\subsection{Penilaian Risiko Penipuan}

Manajemen dapat mengurangi kecurangan di organisasi mereka jika mereka memfokuskan upaya mereka pada kontrol internal; ini dapat dicapai dengan melakukan penilaian risiko dan merancang model risiko untuk organisasi mereka (Edward, 2010; Harris, 2011; Wells, 2011). Penilaian risiko perusahaan harus mencakup pemahaman tentang aset perusahaan, yang mencakup karyawan, properti, peralatan, dan perangkat lunak perusahaan. Memahami aset perusahaan adalah langkah pertama dan paling kritis ketika menilai risiko perusahaan karena aset tidak dapat dilindungi jika tidak diidentifikasi (Edward, 2010).

\subsection{Skala Penipuan}

Skala penipuan dikembangkan melalui analisis terhadap 212 kasus penipuan pada awal 1980-an (Albrecht et al. 1984). Penelitian ini didasarkan pada data yang diperoleh dari auditor internal perusahaan yang menjadi korban penipuan. Albrecht dan rekan-rekannya percaya bahwa penipuan sulit untuk diprediksi dan bahwa pelaku penipuan pekerjaan, sebagai suatu kelompok, sulit untuk mendapatkan profil. Berdasarkan hasil penelitian mereka, Albrecht et al. (1984) mengusulkan skala penipuan, yang bergantung pada dua komponen Segitiga Penipuan, tekanan dan peluang, tetapi menggantikan rasionalisasi dengan integritas pribadi. Gambar 5 adalah representasi visual dari skala penipuan. Mengoperasionalkan skala penipuan, tingkat risiko penipuan ditentukan dengan secara bersama-sama mempertimbangkan tiga kriteria - tekanan, peluang, dan integritas. Misalnya, dalam ilustrasi semuanya ada

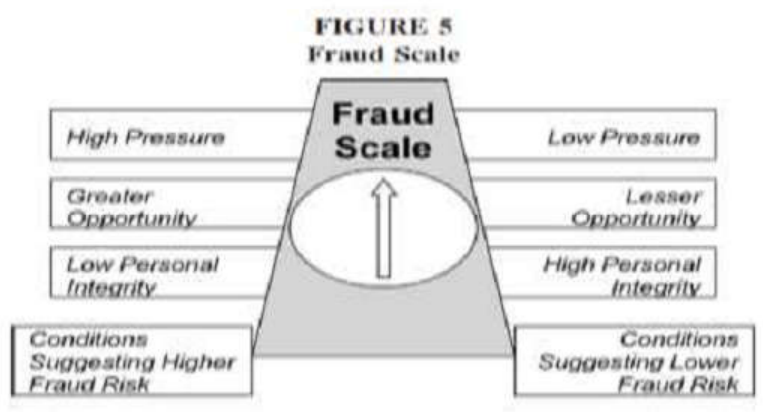


Sebagai contoh, dalam ilustrasi semuanya dalam 'keseimbangan' dan risiko penipuan adalah netral, tetapi ketika tekanan situasional dan peluang yang dirasakan tinggi dan integritas pribadi rendah, penipuan lebih mungkin terjadi daripada ketika yang sebaliknya benar.

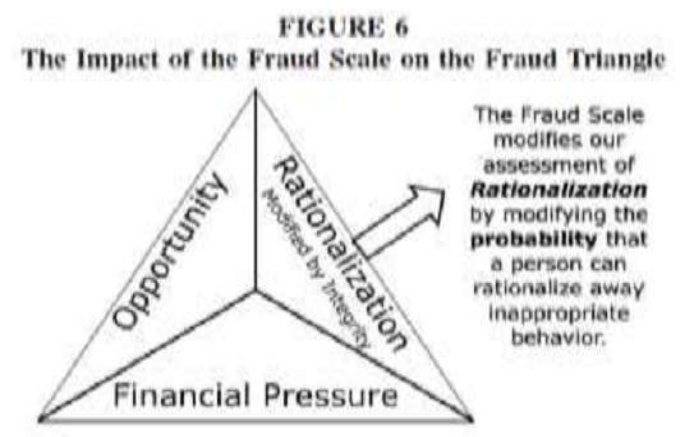

Manfaat memeriksa integritas adalah integritas individu dapat disimpulkan dari perilaku masa lalu. Misalnya, integritas seseorang tercermin dalam keputusannya serta dalam proses pengambilan keputusannya. Lebih penting lagi, integritas pribadi memengaruhi probabilitas bahwa seseorang dapat merasionalisasi perilaku yang tidak pantas. Sebagai contoh, orang dengan integritas yang lebih besar akan cenderung membentuk rasionalisasi untuk membenarkan perilaku yang tidak pantas. Dari perspektif itu, integritas adalah perbaikan dari konstruk rasionalisasi seperti yang disajikan pada Gambar 6 .

\subsection{Predator Versus Penipu yang Tidak Disengaja}

Penipu yang khas sering digambarkan sebagai pelaku pertama kali, paruh baya, berpendidikan tinggi, karyawan tepercaya, dalam posisi tanggung jawab, dan / atau dianggap sebagai warga negara yang baik melalui pekerjaan di masyarakat (ACFE 2009; Ramamoorti et al. 2009). Fraud Triangle menunjukkan bahwa pelaku memiliki masalah tidak dapat dibagikan yang didasarkan pada kekurangan keuangan, dan ketika disejajarkan dengan peluang dan rasionalisasi, warga negara yang baik menyerah untuk melakukan penipuan. Orang ini mungkin dicirikan sebagai penipu yang tidak disengaja.

Terlepas dari tindakan penipuan, penipu yang tidak disengaja itu dianggap sebagai orang yang baik dan taat hukum, yang dalam keadaan normal tidak akan pernah mempertimbangkan pencurian, melanggar hukum, atau merugikan orang lain. Ketika ditemukan, anggota keluarga, sesama karyawan, dan orang lain di komunitas terkejut atau bahkan terkejut dengan perilaku yang diduga oleh sipelaku. Hipotesis Fraud Triangle Cressey membantu komunitas anti penipuan memahami penipu yang tidak disengaja.

Tetapi cepat atau lambat, mengelola laba memberi jalan bagi pelaporan kecurangan finansial, dan penipu yang tidak disengaja menjadi predator. Berkenaan dengan Segitiga Penipuan dan predator, seperti yang digambarkan dalam diatas, tekanan dan rasionalisasi 
memainkan peran sedikit atau tidak sama sekali karena predator hanya membutuhkan kesempatan. Sebagai gantinya, arogansi dan pola pikir kriminal menggantikan anteseden Segitiga Penipuan asli dan rasionalisasi, dan kita dibiarkan dengan unsur-unsur yang berkaitan dengan predator, seperti yang ditunjukkan pada Gambar dibawah ini.

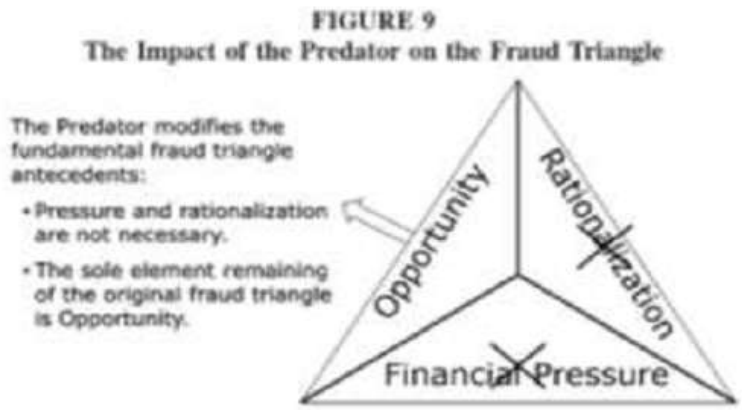

\subsection{Tanggapan Profesi Anti-Penipuan}

Model-meta juga menyediakan kerangka kerja untuk mengevaluasi respons profesi anti-penipuan. umumnya, tindakan anti-penipuan dapat digambarkan sebagai upaya pencegahan, pencegahan, dan deteksi. Pencegahan mengurangi kemungkinan penipuan terutama melalui pengurangan peluang. Sebaliknya, pencegahan mengacu pada menciptakan lingkungan di mana penipuan lebih kecil kemungkinannya terjadi (mis, Lebih kecil kemungkinannya). Secara anekdot, dua penangkal yang paling kuat diyakini adalah ketakutan tertangkap (deteksi) dan takut akan dampak (hukuman).

Mengenai lingkungan anti-penipuan, contoh-contoh pencegahan termasuk upaya untuk menciptakan integritas tempat kerja, nada etis di bagian atas, hotline pengungkap fakta, dan perlindungan pengungkap fakta. Prosedur deteksi digunakan terutama untuk menemukan kejahatan, tetapi jika karyawan menyadari bahwa prosedur deteksi yang ketat sudah ada, mereka mungkin, pada kenyataannya, merupakan bentuk pencegahan (peningkatan kemungkinan ditangkap mengurangi kemungkinan bahwa seseorang akan bertindak).

Aspek berharga lain dari meta-model adalah bahwa ia mengidentifikasi karakteristik yang dapat diuji untuk mempengaruhi probabilitas vektor penipuan. Tujuan keseluruhan dari respons profesi anti-penipuan adalah untuk mengurangi kemungkinan tindakan penipuan dan kejahatan keuangan - yaitu, menurunkan probabilitas vektor penipuan. Model-meta menyediakan kerangka kerja untuk membahas pengaruh yang ditimbulkan dari upaya anti-penipuan individu, serta model untuk membangun lingkungan anti-penipuan yang terpadu dan terkoordinasi. Secara umum, tindakan anti-penipuan yang diimplementasikan dengan baik akan memengaruhi lebih dari satu aspek vektor penipuan; namun, masing-masing memiliki fokus utama. Masing-masing langkah anti-penipuan dibahas secara umum dan dalam konteks meta-model. 


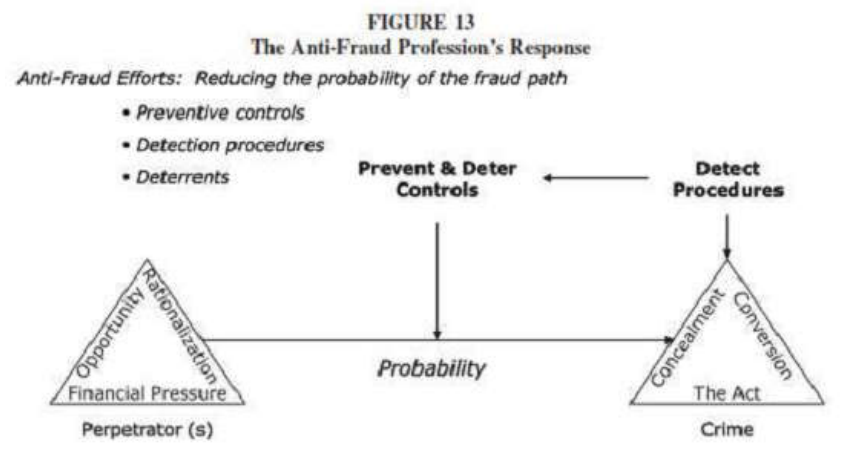

\subsection{Kontrol Internal}

Respon Instruksi Akuntansi Profesi Anti-Penipuan secara tradisional telah berfokus pada kontrol internal — terutama pemisahan tugas — sebagai mekanisme anti-penipuan utama, tetapi kontrol internal tidak semuanya mencakup atau sepenuhnya efektif. Kurangnya keefektifan adalah karena biaya kontrol untuk mencegah setiap penipuan, bahkan yang material, dianggap melebihi manfaatnya. Sebagai tanggapan, organisasi memilih dan memilih kontrol preventif yang diyakini memberikan manfaat terbesar, mengingat kendala anggaran. Tantangan lain adalah kontrol basi - yang usang karena lingkungan bisnis yang berubah dan semakin kompleks - membuat kontrol yang dulu kuat tidak efektif.

Kontrol internal berurusan terutama dengan aspek peluang kejahatan. Penggunaan lingkungan kontrol yang tepat dapat memengaruhi evaluasi penipu potensial terhadap kemungkinan bahwa tindakan tersebut dapat berhasil dilakukan dan disembunyikan. Bahkan jika pelaku mampu melakukan tindakan, kemungkinan penemuan ditingkatkan melalui lingkungan kontrol internal, sehingga secara negatif mempengaruhi persyaratan penyembunyian vektor penipuan.

\subsection{Pencegahan}

Pencegahan penipuan mengacu pada menciptakan lingkungan di mana orang tidak disarankan untuk melakukan penipuan. Manual Pedoman Hukuman Federal AS 2005 mendefinisikan deterensi sebagai pesan jelas yang dikirim ke masyarakat bahwa perilaku kriminal yang berulang akan memperburuk kebutuhan akan peningkatan tingkat hukuman dengan setiap pengulangan berikutnya. Pencegahan penipuan ditingkatkan ketika (1) persepsi deteksi hadir dan (2) pelaku potensial menyadari bahwa mereka akan dihukum ketika tertangkap. Teknik dan kontrol pencegah anti-penipuan (langsung dan tidak langsung) termasuk, tetapi tidak terbatas pada, hal-hal berikut:

a. nada yang kuat di bagian atas

b. budaya etis yang kuat 

c. lingkungan kontrol yang sesuai
d. kode etik yang berarti
e. komunikasi terbuka dengan karyawan,
f. vendor, pemasok, dan pelanggan
g. pemantauan aktivitas karyawan
h. hotline pengungkap fakta
i. perlindungan whistleblower
j. protokol hukuman pelaku
k. pemantauan pihak-pihak kontraktual
1. audit penipuan proaktif

Pencegahan juga dapat dicapai melalui berbagai upaya yang terkait dengan kontrol internal dan program etika yang menciptakan tempat kerja yang berintegritas dan mendorong karyawan untuk melaporkan kesalahan potensial. Tindakan semacam itu meningkatkan kemungkinan yang dirasakan bahwa tindakan penipuan akan terdeteksi dan dilaporkan. Pencegahan penipuan juga dapat dicapai melalui penggunaan perangkat lunak pemantauan/audit berkelanjutan. Sekali lagi, tema utama yang diperlukan untuk pencegah yang efektif adalah untuk menempatkan dalam pikiran penipu bahwa deteksi mungkin terjadi, sehingga mengurangi kemungkinan konversi yang efektif.

\subsection{Menilai Kecurangan Dalam Audit Laporan Keuangan}

Aspek kunci dalam mendeteksi kecurangan adalah membuat rencana audit yang dirancang untuk membantu auditor mengungkap kerentanan dalam sistem yang dapat menimbulkan salah saji material. AU 316 Bagian PCAOB, Pertimbangan Penipuan dalam Audit Laporan Keuangan, dan SAS AICPA yang disusun ulang, Pertimbangan Penipuan dalam Audit Laporan Keuangan, memberikan panduan untuk melakukan audit dengan maksud mengungkap penipuan.Kranacher et al. (2011) mengamati bahwa penipuan, terutama penipuan laporan keuangan, telah menjadi perhatian yang signifikan dari profesi audit, PCAOB, dan SEC. Skandal akhir 1990-an dan awal 2000-an - Enron, Adelphia, WorldCom, dan Tyco - telah meningkatkan tekanan pada auditor untuk mendeteksi pelaporan keuangan yang curang.

Profesi akuntansi merespons pada tahun 2002 dengan SAS No. 99, Pertimbangan Penipuan dalam Audit Laporan Keuangan (AICPA 2002b), 13 yang memberikan panduan tentang penilaian dan menanggapi risiko salah saji material yang timbul dari penipuan. Konsisten dengan standar awal ini, PCAOB dan AICPA terus memberikan arahan dalam menilai dan merespons risiko penipuan yang meliputi: skeptisisme profesional yang dit- 
ingkatkan, brainstorming penipuan pra-audit, menilai risiko atau keberadaan penipuan, dan menanggapi risiko yang diidentifikasi. Meta-model kami memberi tahu profesional menerapkan rencana audit yang peka terhadap kecurangan dengan mengidentifikasi faktor-faktor yang secara langsung mempengaruhi kemungkinan jalur kecurangan. Meskipun kami belum secara spesifik mengidentifikasi bagaimana auditor dapat mengidentifikasi kelemahan tertentu, kami telah menyediakan kerangka kerja untuk mengevaluasi kelemahan di lingkungan kerja.

Artinya, meta-model dapat berguna dalam mengembangkan pendekatan penilaian risiko berdasarkan pemahaman saat ini dari anteseden untuk penipuan.

\subsection{Penilaian Risiko Yang Ditargetkan}

Penilaian risiko yang ditargetkan memperoleh keunggulan yang signifikan sebagai alat evaluatif dan perencanaan ketika diuraikan secara rinci dalam Mengelola Risiko Bisnis Penipuan: Panduan Praktis (IIA et al. 2008). Rezaee dan Riley (2010) danKranacher et al. (2011) mencatat bahwa proses penilaian risiko yang ditargetkan dapat dijelaskan dalam 10 langkah, tetapi pada akhirnya mengevaluasi risiko dalam hal dua atribut utama: kemungkinan dan besarnya penipuan.

Kemungkinan dievaluasi dalam konteks perusahaan, industri, dan lingkungan operasional. Misalnya, industri tertentu sangat rentan terhadap jenis penipuan tertentu. Kedua, besarnya penipuan dinilai dalam hal dampak potensial terhadap kinerja dan kondisi keuangan perusahaan. Pemahaman tentang model bisnis dan lingkungan perusahaan diperlukan untuk mengevaluasi jenis-jenis penipuan yang secara inheren tersedia bagi penipu potensial, dan untuk menilai mana yang paling mungkin terjadi.

\subsection{Penipuan Kolusif Dan Penipuan Manajemen}

Penipuan kolusif dan penggantian manajemen adalah dua dari ancaman yang lebih parah terhadap upaya anti-penipuan. Konsekuensinya, profesi anti-penipuan menargetkan area-area yang berpotensi kolusi atau ditimpa oleh manajemen sebagai hal yang sangat penting. Pihak yang terlibat dalam kolusi dapat berupa individu dalam suatu organisasi, individu lintas organisasi, atau beberapa organisasi, dan sering kali menjangkau beberapa yurisdiksi - lokal, negara bagian, federal, dan internasional. TheACFE's (2008) Report to the Nation menunjukkan bahwa ketika kolusi terlibat, jumlah dolar yang terkait dengan kerugian penipuan meningkat secara dramatis. Kerugian yang disebabkan oleh predator individu bisa sangat besar, tetapi ketika individu-individu itu bekerja bersama-sama dengan orang lain, kerusakannya bisa sangat menghancurkan dan jauh lebih luas.

Penipuan yang dilakukan melalui override manajemen bisa sangat sulit untuk dideteksi. TheAICPA (2005) mengidentifikasi enam rekomendasi utama bagi komite audit 
dalam melaksanakan tugasnya:

a. Pertahankan skeptisisme.

b. Memperkuat pemahaman komite tentang bisnis.

c. Brainstorm untuk mengidentifikasi risiko penipuan.

d. Gunakan kode perilaku untuk menilai budaya pelaporan keuangan.

e. Pastikan entitas mengembangkan program pengungkap fakta yang kuat.

f. Kembangkan jaringan informasi dan umpan balik yang luas.

Mengingat potensi penimpaan manajemen dan paparan signifikan yang diwakilinya, banyak yang merekomendasikan agar komite audit mengambil pendekatan proaktif terhadap penimpaan manajemen dan penipuan kolusif. Mencegah dan mendeteksi penipuan manajemen kolusif memerlukan pencarian skema penipuan secara proaktif.

\section{KECURANGAN (FRAUD)}

\subsection{Klasifikasi Kecurangan}

Association Of Cerified Examiners (ACFE) salah satu asosiasi pemeriksa kecurangan bersetifikat dalam rudhiyansah (2013), mengkategorikan kecurangan dalam tiga kelompok sebagai berikut:

a. Penyimpangan atas aset, meliputi penyalahgunaan/pencurian aset atau harta perusahaan atau pihak lain. Ini merupakan bentuk kecurangan yang paling mudah dideteksi karena sifatnya yang tangible atau dapat diukur/ dihitung.

b. Pernyataan palsu atau salah pernyataan, meliputi tindakan yang dilakukan oleh pejabat atau ekskutif suatu perusahaan atau instansi pemerintah untuk menutupi kondisi keuangan yang sebenarnya dengan melakukan rekayasa keungan dalam penyajian laporan keuangannya untuk memproleh keuntungan

c. Korupsi. Jenis kecurangan ini yang paling sulit didetksi karena menyangkut kerjasama dengan pihak lain seperti suap dan korupsi, dimana hal ini merupakan jenis yang terbanyak terjadi di negara-negara berkembang yang pengakkan hukumnya lemah dan masih kurang kesadaran akan tata kelola yang baik sehingga faktor integritasnya masih dipertanyakan. Jenis kecurangan ini sulit dideteksi karena para pihak saling kerja sama menikmati keuntungan termasuk didalamnya ialah penyalahgunaan wewenang/konflik kepentingan, penyuapan, penerimaan yang tidak sah/ilegal, dan pemerasan secara ekonomi. 


\subsection{Love Of Money}

Uang merupakan aspek yang sangat penting dalam kehidupan sehari-hari. Menurut Rubenstein (2013) di Amerika Serikat, keberhasilan diukur dengan uang dan pendapatan. Herzberg (2013) mengatakan bahwa uang adalah motivator bagi sebagian orang, tetapi orang lain menganggapnya berbeda.

Karena pentingnya uang dan interpretasi yang berbeda, Tang (1992) memperkenalkan konsep cinta uang (love of money) untuk literatur psikologis. Konsep ini berusaha mengukur perasaan subjektif seseorang tentang uang. Tang et all (2008) mendefinisikan love of money sebagai perilaku seseorang terhadap uang, pengertian seseorang terhadap uang, serta keinginan dan aspirasi seseorang terhadap uang. Love of money dapat juga diartikan sebagai level kecintaan seseorang terhadap uang, bagaimana mereka menganggap pentingnya uang bagi kehidupan mereka. Sikap terhadap uang dipelajari melalui proses sosialisasi yang didirikan pada masa kanak-kanak dan dipelihara dalam kehidupan dewasa (Tang et all, 2005).

Money ethic scale (MES) yang dikembangkan oleh Tang (1992) digunakan untuk mengukur sikap etis seseorang terhadap penilaiannya akan uang. Money ethic scale (MES) menghasilkan enam faktor yang diidentifikasi, meliputi good, evil, achievement, respect, budget, dan freedom (Furnham dan Argyle, 2008). Good merupakan gagasan bahwa uang adalah 'baik', yaitu sikap positif terhadap uang. Evil merupakan sikap negatif terhadap uang. Achievement yaitu uang melambangkan prestasi seseorang. Respect (self-esteem) yaitu uang dapat membantu orang mendapatkan harga diri dan rasa hormat dari orang lain. Budget yaitu bagaimana orang menganggarkan uang mereka. Freedom (power) yaitu uang adalah kekuatan, dengan uang, seseorang mampu memiliki otonomi, kebebasan, dan keamanan, menjadi apa yang diinginkan, dan memengaruhi orang lain.

\subsection{Kecerdasan Spritual}

Kecerdasan spiritual (SQ) adalah kecerdasan untuk menghadapi dan memecahkan masalah persoalan makna dan nilai, yaitu kecerdasan untuk menempatkan perilaku dan hidup manusia dalam konteks yang lebih luas dan kaya, kecerdasan untuk menilai bahwa tindakan atau jalan hidup seseorang lebih bermakna disbanding dengan orang lain (Zohar dan Marshall, 2005). Sedangkan menurut Zakiah (2013) kecerdasan spiritual merupakan kemampuan manusia memaknai bagaimana arti dari kehidupan, memahami nilai dari setiap perbuatan yang dilakukan dan kemampuan potensial setiap manusia yang menjadikan seseorang dapat menyadari dan menentukan makna, nilai, moral, serta cinta terhadap kekuatan yang lebih besar sehingga membuat manusia dapat menempatkan diri dan hidup lebih positif dengan penuh kebijaksanaan, kedamaian, dan kebahagiaan yang hakiki.

Definisi kecerdasan spritual yang lebih sesuai dengan perkembangan psikologi mutakhir dijelaskan oleh sinetar. Menurutnya, kecerdasan spritual adalah pikiran yang 
mendapat inspirasi, dorongan, dan efektivitas yang terinspirasi atau penghayatan ketuhanan yang didalamnya kita semua menjadi bagian.

\subsection{Komponen Kecerdasan Spritual}

Zohar dan marshall (2005) menguji kecerdasan spritual dengan hal-hal berikut:

1) Kemampuan bersifat flexsibel yakni mampu menyesuaikan diri secara spontan dan aktif untuk mencapai hasil yang baik, memiliki pandangan yang pragmatis (sesuai kegunaan), dan efisiensi tentang realitas. Unsurunsur bersifat flexsible yaitu mampu menempatkan diri dan dapat menerima pendapat orang lain secara terbuka.

2) Kesadaran diri yang tinggi, yaitu adanya kesadaran yang tinggi dan mendalam sehingga bisa menyadari berbagai situasi yang datang dan menanggapinya. Unsur-unsur kesadaran diri yang tinggi yaitu kemampuan mengetahui tujuan dan visi hidup

3) Kemampuan untuk menghadapi dan memanfaatkan penderitaan yaitu tetap tegar dalam menghadapi masalah serta mengambil hikmah dari setiap masalah itu. Unsur-unsur nya ialah tidak ada penyesalan, tetap tersenyum dan bersikap tenang serta senantiasa berdoa

4) Kemampuan untuk menghadapi dan melampaui rasa sakit yaitu seseorang yang tidak ingin menambah masalah serta kebencian terhadap sesama sehingga mereka berusaha untuk menahan amarah. Unsur-unsurnya ialah kemampuan menghadapi dan melampaui rasa sakit yaitu ikhlas dan pemaaf

5) Kualitas hidup yang diilhami oleh visi dan nilai-nilai yaitu memiliki pemahaman tentang tujuan hidup dan memiliki kualitas hidup. Unsurunsurnya ialah memilikki prinsip, pegangan hidup, dan berpijak pada kebenaran

6) Keengganan untuk berbuat yang merugikan yakni selalu berfikir sebelum bertindak agar tidak terjadi hal yang tidak diharapkan. Unsur-unsurnya ialah tidak menunda perkerjaan dan berfikir sebelum bertindak

Menurut sukidi (2002) terdapat dua metode secara umum, yaitu :

a) Metode vertikal: bagaimana kecerdasan spritual bisa mendidik hati kita untuk menjalin hubungan ke hadirat tuhan

b) Metode horizontal: kecerdsan spritual mendidik hati kedalam budi pekerti yang baik dan moral yang baik.

Implementasi dari metode vertikal, bisa seperti sikap hidup yang religius dan pandai bersyukur atas eksistensi diri. Sedangkan implementasi dari metode horizontal bisa seperti jujur, toleran, beretika, kepedulian sosial yang tinggi.

\section{METODE PENELITIAN}

\subsection{Pendekatan Penelitian}

Penelitian ini merupakan penelitian dengan pendekatan kuantitatif. Penelitian 
kuantitatif menekankan pada pengujian teori-teori melalui pengukuran variabel-variabel penelitian dengan angka dan melakukan analisis data dengan prosedur statistik (Indriantoro dan Supomo, 2014: 12).

Penelitian ini lebih bersifat Correlational Research yang dilakukan dengan menguji pengaruh interaksi variabel independen (variabel $\mathrm{X}$ ) terhadap variabel dependen (variabel Y). Menurut Indriantoro dan Supomo (2014: 27) penelitian kausal komparatif merupakan tipe penelitian dengan karakteristik masalah berupa hubungan sebab-akibat antara dua variabel atau lebih.

\subsection{Teknik Pengumpulan Data}

\subsubsection{Kuesioner}

Kuesioner merupakan teknik pengumpulan data yang dilakukan dengan cara memberi seperangkat pertanyaan atau pernyataan tertulis kepada responden untuk dijawabnya. Menurut Bachtiar (1997) kuesioner atau angket merupakan alat pengumpulan data dalam bentuk pertanyaan-pertanyaan kepada responden, peneliti dapat menghimpun data relevan dengan tujuan penelitian dan memiliki tingkat reliabilitas serta validitas yang tinggi. Sampel dalam penelitian ini berjumlah 98 orang yang merupakan pengelola dana desa di kota langsa.

\subsubsection{Dokumentasi}

Dokumentasi merupakan pengumpulan dan pencatatan dokumen-dokumen yang berkaitan dengan penelitian.

\subsubsection{Instrumen Penelitian}

Instrumen penelitian adalah alat bantu yang digunakan oleh peneliti untuk mengumpulkan informasi kuantitatif tentang variabel yang sedang diteliti. Adapun instrumen yang digunakan dalam penelitian ini adalah dengan menggunakan angket atau kuisioner. Adapun kuesioner untuk mengukur variabel Love of Money (X1), Kecerdasan Spiritual (X2), Kecenderungan Fraud pada penggunaan dana desa (Y). Untuk mengukur pendapat responden digunakan skala Likert. Skala likert adalah skala yang digunkan untuk mengukur sikap, pendapat, dan persepsi seseorang atau sekelompok orang tentang fenomena sosial (Priyatno, 2010). Data diolah dengan menggunakan skala likert dengan jawaban atas pertanyaan yaitu skala 1-5.

\subsubsection{Penguji Instrumen Penelitian}

Sebelum dilakukan analisis data, terlebih dahulu akan dilakukan uji instrumen yang digunakan sebagai alat ukur. Uji ini meliputi uji validitas dan reliabilitas. Setelah uji instrumen kemudian baru dilakukan teknik analisis data. 


\section{HASIL PENELITIAN}

\subsection{Variabel Love Of Money $\left(X_{1}\right)$}

Berdasarkan data yang di peroleh dari 98 responden, maka di peroleh hasil frekuensi Jawaban responden yang disajikan dalam bentuk frekuensi dan persentase sebagai berikut:

1). Uang merupakan faktor sangat penting dalam kehidupan kita semua.

2). Uang melambangkan prestasi seseorang.

3). Uang memberi saya segalanya.

4). Uang membuat saya dihormati dalam sebuah kelompok/komunitas.

5). Uang dapat membuat saya memiliki banyak teman

\section{Variabel Kecerdasan Spiritual $\left(\mathrm{X}_{2}\right)$}

Berdasarkan data yang di peroleh dari 98 responden, maka di peroleh hasil frekuensi Jawabann responden yang disajikan dalam bentuk frekuensi dan persentase sebagai berikut:

1). Saya tidak lupa berdo'a sebelum melakukan sesuatu.

2). Cobaan datang dari tuhan saya anggap sebagai ujian keimanan saya

3). Biasanya saya bersikap sabar menerima kesusahan.

4). Saya selalu berfikir positif dalam menghadapi berbagai persoalan hidup yang saya alami.

\section{Variabel Kecenderungan Fraud (Y)}

Berdasarkan data yang di peroleh dari 98 responden, maka di peroleh hasil frekuensi Jawabann responden yang disajikan dalam bentuk frekuensi dan persentase sebagai berikut:

1. Suatu hal yang wajar di instansi saya, apabila untuk suatu tujuan tertentu, biaya, dicatat lebih besar dari semestinya.

2. Bukan suatu masalah bagi instansi saya, apabila pencatatan bukti transaksi dilakukan tanpa otoritas dari pihak berwenang.

3. Suatu yang wajar di instansi saya, apabila untuk tujuan, harga beli peralatan, perlengkapan kantor dicatat lebih tinggi.

\subsection{Uji Validitas dan Uji Reabilitas}

\subsubsection{Uji Validitas}

Uji validitas digunakan untuk mengukur sah atau valid tidaknya suatu kuesioner. Suatu kuesioner dikatakan valid jika pertanyaan pada kuesioner mampu untukmengungkapkan sesuatu yang akan diukur oleh kuesioner tersebut (Ghozali, 2009).Dalam hal ini digunakan beberapa butir pertanyaan yang dapat secara tepatmengungkapkan variabel 
yang diukur tersebut Dalam hal ini digunakan beberapa butir pertanyaan yang dapat secara tepatmengungkapkan variabel yang diukur tersebut. Setiap faktor dianggap valid jika corrected Item-Total Correlation>0,30 (Sugiyono, 2013:179).

Tabel: Uji Validitas

\begin{tabular}{lccc}
\hline $\begin{array}{l}\text { Indikator Variabel independen } \mathbf{X}_{\mathbf{1}} \mathbf{X}_{\mathbf{2}} \text { dan depen- } \\
\text { den Y }\end{array}$ & $\begin{array}{c}\text { Pearson Cor- } \\
\text { relation }\end{array}$ & $\begin{array}{c}\text { Korelasi } \\
\text { Minimal }\end{array}$ & Ket. \\
\hline Variabel $\mathrm{X}_{1}$ Love Of Money & 0,551 & $>0,30$ & Valid \\
VariabelX Kecerdasan Spiritual & $0,610(-0,61)$ & $>0,30$ & Valid \\
Variabel Y Kecenderungan Fraud & 1.000 & $>0,30$ & Valid \\
\hline
\end{tabular}

Sumber: Hasil Penelitian, Data diolah. 2019

Hasil pengujian validitas menunjukkan bahwa seluruh indikator independent dan dependent menghasilkan faktor corrected Item-Total Correlation $>0,30$ dimana indikator variabel Love Of Money dilambangkan dengan $\mathrm{X}_{1}$ total nilai indikatornya 0,551. Kecerdasan Spiritual dilambangkan dengan $\mathrm{X}_{2}$ total nilai indikatornya 0,610. dan Kecenderungan Fraud dilambangkan dengan Y total nilai indikatornya 1.000.

\subsubsection{Uji Reliabilitas}

Uji reliabilitas digunakan untuk mengukur suatu kuesioner yang merupakan indikator dari variabel. Suatu kuesioner dapat dikatakan reliabel atau handal apabila Jawabann seseorang terhadap pernyataan adalah stabil atau konsisten dari waktu ke waktu. Suatu variabel dikatakan handal apabila nilai croanbach alpha $(\alpha)$ lebih besar dari 0,60. Namun apabila nilai croanbach alpha lebih kecil 0,60 maka kuesioner dianggap kurang handal sehingga apabila dilakukan penelitian ulang terhadap variabel-variabel tersebut pada waktu dan dimensi yang bebeda, kesimpulannya akan berbeda (Ghozali, 2011).

Tabel : Uji Reabilitas

\begin{tabular}{llcccc}
\hline No. & \multicolumn{1}{c}{ Variabel } & N & Mean & $\begin{array}{c}\text { Korelasi } \\
\text { Minimal }\end{array}$ & Keterangan \\
\hline 1. & Love Of Money $\mathrm{X}_{1}$ & 98 & 16,82 & $>0,30$ & Reliabel \\
2. & Kecerdasan Spiritual $\mathrm{X}_{2}$ & 98 & 21,11 & $>0,30$ & Reliabel \\
3. & Kecenderungan Fraud $\mathrm{Y}$ & 98 & 8,24 & $>0,30$ & Reliabel \\
\hline
\end{tabular}

Sumber : Hasil Penelitian, Data diolah. 2019

Dapat dilihat bahwa nilai Mean untuk independent variable yaitu variabel Love Of Money $\left(\mathrm{X}_{1}\right)$ sebesar 16,82. variabel Kecerdasan Spiritual $\left(\mathrm{X}_{2}\right)$ sebesar 21,11 dan untuk dependent variable yaitu Kecenderungan Fraud (Y) memiliki nilai mean sebesar 8,24. Dari hasil data yang diolah melalui SPSS dapat disimpulkan bahwa keseluruhan variabel yang diteliti reliabel. 


\subsection{Uji Asumsi Klasik}

\subsubsection{Uji normalitas}

Uji normalitas bertujuan menguji apakah dalam model regresi, variabel pengganggu atau residual memiliki distribusi normal. Kita dapat melihat dari normal probability plotyang membandingkan distribusi kumulatif dengan distribusi normal. Distribusi normal membentuk suatu garis lurus diagonal, dan plotting data residual akan dibandingkan dengan garis diagonalnya. Jika data terdistribusi normal, maka garis yang menggambarkan data sebenarnya akan mengikuti garis normalnya (Ghozali,2005).

Gambar : Uji Normalitas

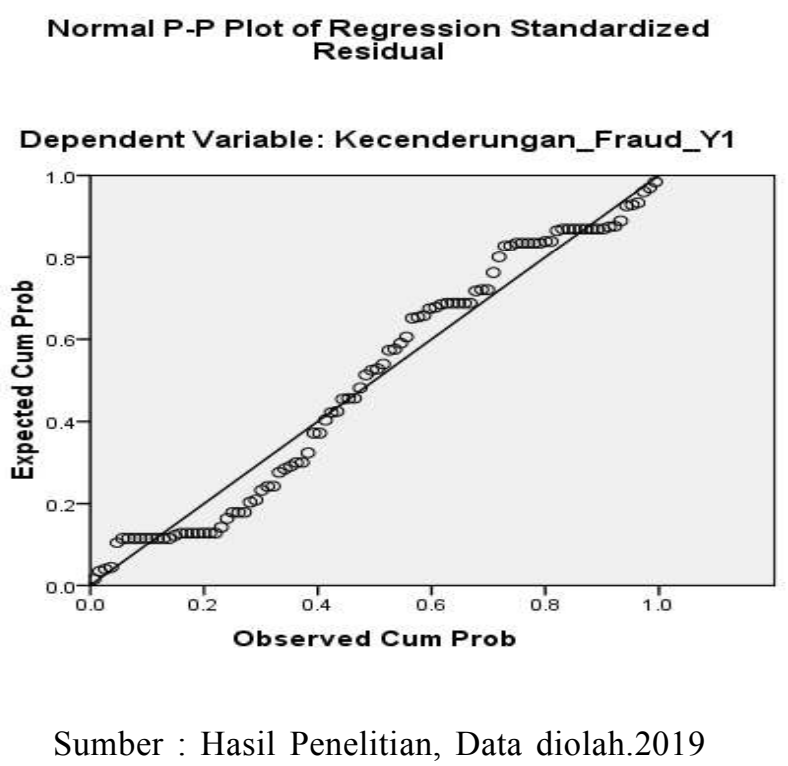

Setelah melihat hasil Gambar di atas Normal P-Plot maka dapat disimpulkan bahwa model regresi memenuhi asumsi normalitas karena pada grafik normal P-Plot rerlihat titik - titik mendekati garis diagonal dan menyebar disekitar garis diagonal dan menunjukkan hasil yang sangat signifikan.

\subsubsection{Uji Multikolinieritas}

Uji multikolinieritas bertujuan untuk menguji apakah model regresi ditemukan adanya hubungan yang kuat diantara variabel bebas (independent), apabila terjadi korelasi, Ghozali (2011). Model regresi yang baik seharusnya tidak terjadi korelasi diantara variabel independen. Jika variabel independen saling berkorelasi, maka variabel-variabel ini tidak ortogonal. Variabel ortogonal adalah variabel independen yang nilai korelasi antar sesama variabel independen sama dengan nol. Menurut Ghozali (2009) Uji Multikolinieritas bertujuan untuk menguji dalam model regresi ditemukan adanya korelasi antar variabel - variabel bebas. Uji ini dilakukan dengan melihat Tolerance dan Variance Inflation factor (VIF). Nilai Tolerance yang rendah sama dengan nilai VIF yang tinggi 
karena VIF $=1 /$ Tolerance) .

Jika nilai tolerance atau nilai Variance inflaction Factor $(\mathrm{VIF})>10$ berarti dapat disimpulkan adanya multikolinearitas. Namun sebaliknya jika hasil perhitungan nilai nilai tolerance atau nilai Variance inflaction Factor (VIF) $<10$ maka dapat disimpulkan bahwa tidak terjadi multikolinearitas antar variabel independent.

Tabel : Uji Multikolinearitas

\begin{tabular}{lcc}
\hline \multirow{2}{*}{ Variabel Independen } & \multicolumn{2}{c}{ Collinearity Statistics } \\
\cline { 2 - 3 } & Tolerance & VIF \\
\hline Love Of Money & 0.978 & 1.023 \\
Kecerdasan Spiritual & 0.978 & 1.023 \\
\hline
\end{tabular}

Sumber: Hasil Penelitian, Data diolah.2019

Pada tabel 4.6.3 dapat disimpulkan bahwa nilai VIF untuk kedua variabel yaitu $<$ 10 untuk variabel X1Love Of Money sebesar 1,023, nilai VIFuntuk X2Kecerdasan Spiritual sebesar 1,023. Jadi dapat disimpulkan bahwa tidak adanya multikolinieritas antar variabel yang diteliti.

\subsubsection{Uji Heteroskedastisitas}

Uji heteroskedastisitas bertujuan menguji apakah dalam model regresi terjadi ketidaksamaan varian dari residual satu pengamatan ke pengamatan yang lain. Jika varian dari residual satu pengamatan ke pengamatan lain tetap, maka disebut homoskedastisitas dan jika varian berbeda disebut heteroskedastisitas. Model regresi yang baik adalah yang homoskedastisitas atau tidak terjadi hiteroskedastisitas, Ghozali (2011). Ada beberapa metode pengujian yang dapat digunakan untuk mendeteksi ada tidaknya heteroskedastisitas diantaranya, yaitu

Uji Spearman's rho, Uji Glejser, Uji Park dan melihat pola grafik regresi. Pada penelitian ini digunakan dua metode yaitu Uji scatterplot.

Deteksi ada atau tidaknya heteroskedastisitas dapat juga dilakukan dengan melihat ada tidaknya pola tertentu pada grafik plot scatterplot antara SRESID dan (ZPRED) dimana sumbu $Y$ adalah $Y$ yang telah diprediksi dan sumbu $X$ adalah residual (Y prediksi-Y sesungguhnya) yang telah di-studentized, Ghozali (2011). Untuk lebih jelasnya berikut adalah gambar dari hasil oleh data uji heteroskedastisitas: 
Gambar : Uji Heteroskedastisitas

Scatterplot

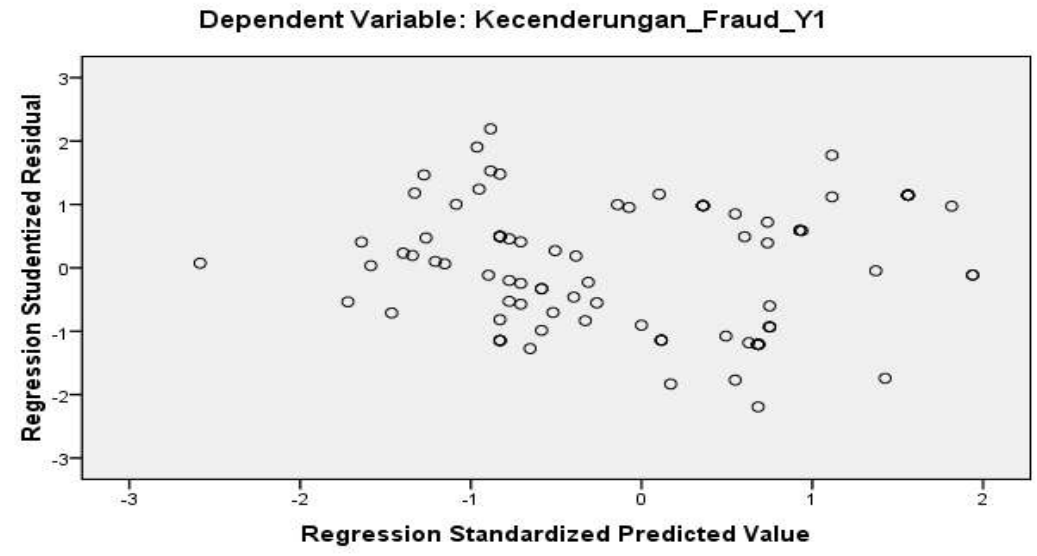

Sumber: Hasil Penelitian, Data diolah.2019

Pada gambar diatas dapat dilihat bahwa titik - titik tersebar ke berbagai arah, baik diatas maupun bawah angka 0 pada sumbu $\mathrm{Y}$ dan tidak membentuk pola tertentu. Jadi dapat disimpulkan bahwa tidak terjadi heteroskedastisitas pada model regresi.

\subsubsection{Model Analisis Data}

Analisis data yang digunakan dalam penelitian ini adalah analisis kuantitatif dengan persamaan regresi linier berganda. Analis kuantitatif yaitu analisis yang digunakan untuk menganalisa data yang diperoleh dari pertanyaan yang memerlukan perhitungan statistik, sehingga analisis ini sering disebut dengan analisis statistik. Untuk menguji hipotesis pengaruh penilaian Love Of Money $\left(\mathrm{X}_{1}\right)$,Kecerdasan Spiritual $\left(\mathrm{X}_{2}\right)$ Kecenderungan Fraud (Y).

\section{PENGUJIAN HIPOTESIS}

\subsection{Uji Signifikansi Pengaruh Parsial (Uji t)}

Priyatno (2010:68) menjelaskan bahwa uji t digunakan untuk mengetahui apakah dalam model regresi variabel bebas (independent) (X) secara parsial (masing-masing) berpengaruh signifikan terhadap variabel terikat (dependent) (Y). Uji ini dilakukan untuk mengetahui hubungan variabel bebas (independent) yaitu Love Of Money $\left(\mathrm{X}_{1}\right)$, Kecerdasan Spiritual $\left(\mathrm{X}_{2}\right)$, terhadap Kecenderungan Fraud pada penggunaan dana desa.

$\alpha=5 \%$ jika nilai $\mathrm{t}_{\text {hitung }}$ dengan probabilitas $<\alpha=5 \%$ maka dapat disimpulkan bahwa variabel bebas (independent) berhubungan dengan variabel terikat (dependent). Model hipotesis yang digunakan adalah:

a. $\mathrm{t}_{\text {hitung }}>\mathrm{t}_{\text {tabel }}$ dengan $\alpha=5 \% \mathrm{H}_{1}, \mathrm{H}_{2}$, diterima, artinya Love Of Money $\left(\mathrm{X}_{1}\right)$, dan Kecerdasan Spiritual $\left(\mathrm{X}_{2}\right)$ berhubungan secara parsial terhadap Kecenderungan 
Fraud pada penggunaan dana desa.

b. $\mathrm{t}_{\text {hitung }}<\mathrm{t}_{\text {tabel }}$ dengan $\alpha=5 \% \mathrm{H}_{1}, \mathrm{H}_{2}$, ditolak, artinya Love Of Money $\left(\mathrm{X}_{1}\right)$, dan Kecerdasan Spiritual $\left(\mathrm{X}_{2}\right)$ terhadap Kecenderungan Fraud Tidak berhubungan secara parsial terhadap penggunaan dana desa.

Tabel : Uji Parsial

\begin{tabular}{ccccccc}
\hline \multirow{2}{*}{ Model } & \multicolumn{2}{c}{$\begin{array}{c}\text { Unstandardized Coef- } \\
\text { ficients }\end{array}$} & $\begin{array}{c}\text { Standardized } \\
\text { Coefficients }\end{array}$ & \multirow{2}{*}{ T } & \multirow{2}{*}{ Sig. } \\
\cline { 2 - 4 } & $\mathbf{B}$ & Std. Error & Beta & & \\
\hline (Constant) & 6.967 & 3.172 & & 2.196 & .030 \\
Love Of Money & .399 & .059 & .529 & 6.719 & .000 \\
Kecerdasan Spiritual & -.257 & .149 & -.147 & -1.726 & .088 \\
\hline
\end{tabular}

Sumber : Hasil Penelitian, Data diolah.2019

Hasil pengujian uji t dijelaskan sebagai berikut:

\section{Variabel Love Of Money $\left(\mathrm{X}_{1}\right)$}

a. Jika $\mathrm{t}_{\text {hitung }}>\mathrm{t}_{\text {tabel }} \mathrm{H}_{1}$ diterima, artinya Love Of Money berpengaruh parsial terhadap Kecenderungan Fraud pada pengunaan dana desa.

b. Jika $\mathrm{t}_{\text {hitung }}<\mathrm{t}_{\text {tabel }} \mathrm{H}_{1}$ ditolak, artinya Love Of Money tidak berpengaruh parsial terhadap Kecenderungan Fraud pada penggunaan dana desa.

Hasil perhitungan regresi menunjukkan bahwa hipotesis $\mathrm{H} 1$ diterima, hal ini berarti bahwa Love Of Money (X1) berhubungan secara parsial terhadap Kecenderungan Fraud pada penggunaan dana desa.Hal tersebut ditunjukkan dengan nilai thitung sebesar 6.719 dan lebih besar dari nilai ttabel 1,660551 (df=n-k-1) pada $\mathrm{n}=98$ sebesar. Pada level $5 \%$ dan nilai signifikan sebesar $0,001<0,05$.

\section{Variabel Kecerdasan Spiritual (X2)}

a. Jika $t_{\text {hitung }}>\mathrm{t}_{\text {tabel }} \mathrm{H}_{2}$ diterima, artinya Kecerdasan Spiritual berpengaruh parsial terhadap pada penggunaan dana desa.

b. Jika $\mathrm{t}_{\text {hitung }}<\mathrm{t}_{\text {tabel }} \mathrm{H}_{2}$ ditolak, artinya Kecerdasan Spiritual tidak berpengaruh parsial terhadap Kecenderungan Fraud pada penggunaan dana desa.

Hasil perhitungan regresi menunjukkan bahwa hipotesis $\mathrm{H} 2$ diterima, hal ini berarti bahwa Kecerdasan Spiritual (X2) tidak berhubungan secara parsial terhadap Kecenderungan Fraudpada penggunaan dana desa.Hal tersebut ditunjukkan dengan nilai thitung sebesar -1,726dan lebih kecil dari nilai ttabel 1,660551 (df=n-k-1) pada $n=51$ sebesar . Pada level $5 \%$ dan nilai signifikan sebesar $0,000<0,05$. 
Uji Signifikansi Pengaruh Simultan (Uji F)

Uji signifikan parameter simultan digunakan untuk mengetahui hubungan variabel bebas (independent) terhadap variabel terikat (dependent) secara simultan (bersama-sama). Uji F dilakukan secara serentak untuk membuktikan hipotesis awal hubungan variabel bebas (independent) Love Of Money $\left(\mathrm{X}_{1}\right)$, Kecerdasan Spiritual $\left(\mathrm{X}_{2}\right)$ terhadap variabel terikat (dependent) yaitu Kecenderungan Fraud (Y). pada penggunaan dana desa, yang menjadi perbandingkan antara nilai profitabilitas dengan nilai signifikan $\alpha=5 \%$. Jika nilai $\mathrm{F}_{\text {hitung }}$ dengan profitabilitas $<\alpha=5 \%$ maka dapat disimpulkan bahwa variabel bebas (independent) memiliki hubungan terhadap variabel terikat (dependent).

Model hipotesis yang digunakan adalah:

a. $\quad \mathrm{F}_{\text {hitung }}>\mathrm{F}_{\text {tabel }}$ dengan $\alpha=5 \%$ maka $_{3}$ diterima , artinya Love Of Money $\left(\mathrm{X}_{1}\right)$, Kecerdasan Spiritual $\left(\mathrm{X}_{2}\right)$ berhubungan secara simultan terhadap Kecenderungan Fraud pada penggunaan dana desa (Y).

b. $\quad \mathrm{F}_{\text {hitung }}<\mathrm{F}_{\text {tabel }}$ dengan $\alpha=5 \%$ maka $\mathrm{H}_{3}$ ditolak, artinya Love Of Money $\left(\mathrm{X}_{1}\right)$, Kecerdasan Spiritual $\left(\mathrm{X}_{2}\right)$ Tidak berhubungan secara simultan terhadap Kecenderungan Fraud pada penggunaan dana desa. (Y).

Tabel : Uji Simultan

\begin{tabular}{cccc}
\hline F Change & df1 & df2 & Sig. F Change \\
\hline 22.837 & 2 & 98 & .000 \\
\hline
\end{tabular}

Sumber: Hasil Penelitian, Data diolah 2019

Berdasarkan tabel di atas hasil perhitungan yang diperoleh pada tabel diatas, dapat diketahui bahwa nilai Fhitung lebih besar dari nilai Ftabel $>3,08$, dan nilai signifikan $(\operatorname{sig})=0,000$ yang lebih kecil dari nilai $\alpha=0,05$. Hasil perhitungan regresi menunjukkan bahwa hipotesis H3 diterima. Hal ini berarti bahwa artinya Love Of Money (X1), dan Kecerdasan Spiritual(X2) berpengaruh terhadap Kecenderungan Fraud pada penggunaan dana desa (Y).

\section{Korelasi (R) Dan Determinasi $\left(\mathbf{R}^{2}\right)$}

\section{Korelasi Love Of Money Dan Kecerdasan Spiritual Terhadap Kecenderungan Fraud Pada Penggunaan Dana Desa.}

Untuk melihat besarnya hubungan dari masing-masing variabel dengan melihat nilai $\mathrm{R}$ dapat dijelaskan pada Tabel berikut ini: 
Tabel : Korelasi (R) dan Determinasi (R2)

\begin{tabular}{ccccc}
\hline Model & $\mathbf{R}$ & R Square & Adjusted R Square & Std. Error of the Estimate \\
\hline 1 & $.570^{\mathrm{a}}$ & .325 & .310 & 3.077 \\
\hline
\end{tabular}

Sumber: Hasil Penelitian, Data diolah.2019

Berdasarkan hasil pengujian dari tabel diatas diperoleh nilai $\mathrm{R}$ sebesar 0,570 atau $57 \%$ yang berarti bahwa variabel Love Of Money dan Kecerdasan Spiritual mempunyai hubungan korelasi yang sangat kuat dan positif terhadap Kecenderungan Fraud pada penggunaan dana desa.

\section{Koefisien Love Of Money Dan Kecerdasan Spiritual Terhadap}

\section{Kecenderungan Fraud Pada Penggunaan Dana Desa}

Menurut Kuncoro (2004), koefisien determinasi $\left(\mathrm{R}^{2}\right)$ pada intinya mengukur seberapa jauh kemampuan model dalam menerangkan variasi variabel terikat. Kelemahan mendasar penggunaan koefisien determinasi adalah bias terhadap jumlah variabel independen yang dimasukkan ke dalam model.

Koefesien diterminasi dengan simbol $\mathrm{R}^{2}$ merupakan proporsi variabilitas dalam suatu data yang dihitung didasarkan pada model statistik. Definisi berikutnya menyebutkan bahwa $\mathrm{R}^{2}$ merupakan rasio variabilitas nilai-nilai yang dibuat model dengan variabilitas nilai data asli. Secara umum $\mathrm{R}^{2}$ digunakan sebagai informasi mengenai kecocokan suatu model. Dalam regresi $\mathrm{R}^{2}$ ini dijadikan sebagai pengukuran seberapa baik garis regresi mendekati nilai data asli yang dibuat model. Jika $\mathrm{R}^{2}$ sama dengan 1 , maka angka tersebut menunjukkan garis regresi cocok dengan data secara sempurna.

Nilai koefisien determinasi dapat dilihat pada tabel 4.6.8 Nilai $\mathrm{R}^{2}$ menunjukkan besarnya kontribusi pengaruh variabel bebas terhadap variabel terikat dalam sebuah model. Hasil perhitungan yang disajikan pada tabel diatas menunjukkan nilai $\mathrm{R}^{2}=0,325$ atau 32.5\%yang berarti bahwa Kecenderungan Fraud pada penggunaan dana desa dapat dijelaskan dan dipengaruhi oleh variabel bebas Love Of Money $\left(\mathrm{X}_{1}\right)$, dan Kecerdasan Spiritual $\left(\mathrm{X}_{2}\right)$ Sedangkan sisanya yaitu $0,10 \mathrm{atau} 10 \%$ dipengaruhi oleh variabel-variabel lain yang tidak termasuk dalam penelitian.

\section{KESIMPULAN}

Pada penelitian, mengukur tingkat kecurangan pada penggunaan dana desa, pada penelitian ini menggunakan dua variabel yaitu variabel terikat (kecenderungan kecurangan pada penggunaan dana desa) dan variabel bebas (sifat love of money dan kecerdasan spritual). Hasil perhitungan regresi menunjukkan Love Of Money (X1) berpengaruh se- 
cara parsial terhadap Kecenderungan Fraud pada penggunaan dana desa. Sedangkan Kecerdasan Spiritual (X2) tidak berpengaruh secara parsial terhadap Kecenderungan Fraud pada penggunaan dana desa.

Kesimpulan dari pembahasan diatas menunjukan bahwa terjadinya fraud pada penggunaan dana desa disebabkan oleh beberapa faktor dan dalam penelitian ini sangat sejalan dengan penelitian terdahulu, bahwa dimensi fraud tersebut tidak lepas dari regulasi, tata kelola, pengawasan dan lemahnya SDM.

\section{DAFTAR PUSTAKA}

Al-Qur'an Cordoba, amazing,33 tuntunan al-quran untuk hidup anda, bandung:internasional-indonesia, cet. Pertama, 2012

Ar-Raqib Al-Asfahani, Mu’jam Mufradat li Alfazil qur'ani, 1431 H/2010 M

Afria lisda, pengaruh kemampuan intelektual, kecerdasan emosional, dan kecerdasan spritual terhadap perilaku etis auditor serta dampaknya terhadap kinerja, skripsi, fakultas ekonomi dan ilmu sosial UIN syarif hidayatullah, 2009

Farah Zakiah, Pengaruh Kecerdasan Intelektual, Kecerdasan Emosional, Dan Kecerdasan Spritual Terhadap Pemahaman Akutansi, Skripsi, Fakultas Ekonomi Universitas Jember, 2013

Ferawati Harun, Pengaruh Sifat Machiavelian Dan Love Of money Terhadap Perilaku Etis Auditor, Skripsi, fakultas ekonomi dan bisnis islam UIN Alauddin Makassar, 2016

Nurul Azisah, Pengaruh Love Of Money Dan Kecerdasan Spritual Terhadap Kecendrungan Fraud Dalam Penggunaan Dana Dengan Gender Sebagai Variabel Moderating, Skripsi, Fakultas Ekonomi Dan Bisnis Islam UIN Alauddin Makassar, 2017

Yuliani, Pengaruh Kepemimpinan Kepala Desa Terhadap Pembiayaan Program Pembangunan Yang Bersumber Dari Alokasi Dana Desa, Skripsi, Fakultas Ekologi Manusia Institut Pertanian Bogor, 2017 